\title{
Occupational Health Nursing: A Specialty under Debate
}

\section{Javier González-Caballero*}

Prevention and Occupational Health Service, National Institute of Social Security, Bilbao, Spain

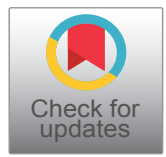

*Corresponding author: Javier González-Caballero, Prevention and Occupational Health Service, National Institute of Social Security, Gran Vía de Don Diego López de Haro, 62. 48011 Bilbao, Spain

\begin{abstract}
The exercise of occupational health nursing based on the acquisition of competencies allows them to fully carry out their tasks, acquire levels of autonomous decision, make their role visible as a collective and record their contribution in this very specific work scenario. Considering the active role it plays in the context of organizations, its contribution allows guaranteeing the well-being of the people who are the object of its care, the working population.
\end{abstract}

\section{Keywords}

Occupational health, Occupational health nursing, Professional competence

The occupational health nursing specialty has a long history in the field of specialized care due to its specific training and presence in the workplace [1]. Their professional training to develop their skills is endorsed by extensive regulatory support, occupying a necessary space in the process of improving not only working conditions but also in increasing the quality of life at work [2].

In the history of this specialty, her professional development has run parallel to the evolution of the nursing profession itself. In this way, with the publication in Spain which approves and publishes the first training program in the specialty of occupational health nursing, a new framework of action based on the development and application of the approved competencies in the following areas: prevention, clinical care services, legal expertise, management, teaching and research, carrying out the acquisition process in the multidisciplinary teaching units through the residence system [3].

This exercise of the profession based on the approved competences allows them to carry out their duties fully, acquire levels of autonomous decision $[4,5]$, make their role visible as a collective and record their contribution in this very specific work scenario. Therefore, the development that this discipline carries out of its attributions contributes to the construction of a collective identity, to a search for excellence in professional practice $[6,7]$.

For some time now, the specialty is immersed in a complex, diverse and variable work environment. In this scenario, significant changes are taking place, which are creating new challenges for the health and safety of workers $[8,9]$. This context poses to occupational health nursing not only practical and technical issues but also ethical aspects, relationships with the organization and also interpersonal ones, seeking professional development and trying to offer a nursing product that aspires to excellence. Thus, the professional possibilities have undergone a progressive evolution in a short period of time, therefore we must consider not only the responses to the substantial modifications in the demand for care based on the acquisition of professional skills, but also be able to agree on which is the professional offer to be developed [10].

In this way, the presence of this specialty in the workplace means an improvement in the assistance provided to workers, it favors the protection of the health of the population that is the object of our care, promotes the establishment of healthy habits in the workplace and prevents health problems related or aggravated by working conditions or professional activity. For this, not only the individual circumstances of each worker will be considered, but also the specific characteristics of the job or the tasks they perform and their possible health problems not strictly related to it $[11,12]$.

Different authors reflect on the development of the professional attributions of our discipline and agree 
Table 1: Competencies of occupational health nursing.

\begin{tabular}{|c|c|c|c|c|c|c|c|c|c|c|c|c|c|c|c|c|c|c|c|c|}
\hline Country & 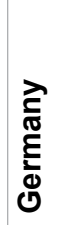 & $\frac{\frac{5}{5}}{\frac{5}{0}}$ & $\begin{array}{l}\frac{\pi}{2} \\
\frac{\pi}{\pi} \\
\stackrel{0}{0}\end{array}$ & $\sum_{0}^{\frac{n}{2}}$ & 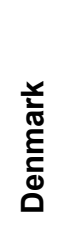 & 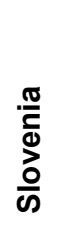 & $\begin{array}{l}\frac{5}{\sqrt[\pi]{0}} \\
\text { की }\end{array}$ & $\frac{\text { O }}{\frac{\text { Tn}}{\underline{I}}}$ & 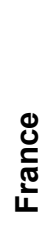 & $\stackrel{x}{\underline{x}}$ & 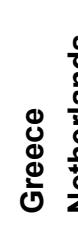 & 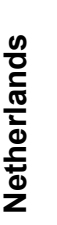 & $\begin{array}{l}\frac{\lambda}{0} \\
\frac{5}{0} \\
\frac{5}{3} \\
\text { T }\end{array}$ & 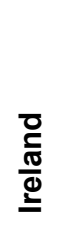 & $\frac{\pi}{\frac{\pi}{\pi}}$ & $\begin{array}{l}\overline{\mathbb{T}} \\
\frac{O}{2} \\
\frac{t}{0} \\
0\end{array}$ & 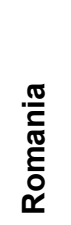 & $\begin{array}{c}\frac{c}{0} \\
\frac{0}{0} \\
\vdots \\
\vdots\end{array}$ & 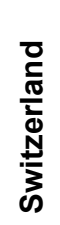 & 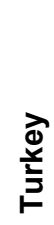 \\
\hline Health education/promotion & $\bullet$ & $\bullet$ & $\bullet$ & $\bullet$ & $\bullet$ & $\bullet$ & $\bullet$ & $\bullet$ & $\bullet$ & $\bullet$ & - & $\bullet$ & $\bullet$ & $\bullet$ & $\bullet$ & $\bullet$ & & $\bullet$ & $\bullet$ & $\bullet$ \\
\hline Disease/injury prevention & $\bullet$ & $\bullet$ & & $\bullet$ & $\bullet$ & $\bullet$ & $\bullet$ & $\bullet$ & $\bullet$ & $\bullet$ & $\bullet$ & $\bullet$ & $\bullet$ & $\bullet$ & $\bullet$ & $\bullet$ & $\bullet$ & $\bullet$ & $\bullet$ & - \\
\hline $\begin{array}{l}\text { Health assistance/ } \\
\text { surveillance }\end{array}$ & & $\bullet$ & $\bullet$ & $\bullet$ & $\bullet$ & $\bullet$ & $\bullet$ & $\bullet$ & $\bullet$ & $\bullet$ & - & $\bullet$ & $\bullet$ & $\bullet$ & $\bullet$ & $\bullet$ & & $\bullet$ & $\bullet$ & $\bullet$ \\
\hline First aid services & & $\bullet$ & & $\bullet$ & $\bullet$ & $\bullet$ & $\bullet$ & $\bullet$ & $\bullet$ & & $\bullet$ & $\bullet$ & $\bullet$ & $\bullet$ & & $\bullet$ & $\bullet$ & $\bullet$ & $\bullet$ & $\bullet$ \\
\hline $\begin{array}{l}\text { Administration of } \\
\text { occupational health service }\end{array}$ & $\bullet$ & $\bullet$ & $\bullet$ & $\bullet$ & $\bullet$ & $\bullet$ & $\bullet$ & $\bullet$ & $\bullet$ & & - & $\bullet$ & $\bullet$ & $\bullet$ & & $\bullet$ & & $\bullet$ & $\bullet$ & $\bullet$ \\
\hline $\begin{array}{l}\text { Sickness absence } \\
\text { management }\end{array}$ & & & & $\bullet$ & $\bullet$ & $\bullet$ & $\bullet$ & $\bullet$ & $\bullet$ & $\bullet$ & $\bullet$ & $\bullet$ & $\bullet$ & $\bullet$ & $\bullet$ & $\bullet$ & $\bullet$ & $\bullet$ & $\bullet$ & $\bullet$ \\
\hline Rehabilitation/resettlement & & $\bullet$ & & $\bullet$ & $\bullet$ & & & $\bullet$ & $\bullet$ & $\bullet$ & - & $\bullet$ & $\bullet$ & $\bullet$ & & $\bullet$ & $\bullet$ & $\bullet$ & $\bullet$ & $\bullet$ \\
\hline $\begin{array}{l}\text { Environmental surveys/ } \\
\text { controls }\end{array}$ & $\bullet$ & $\bullet$ & & $\bullet$ & $\bullet$ & $\bullet$ & $\bullet$ & $\bullet$ & $\bullet$ & & $\bullet$ & & $\bullet$ & $\bullet$ & & & & $\bullet$ & & $\bullet$ \\
\hline Workplace risk assessment & & $\bullet$ & & $\bullet$ & $\bullet$ & & $\bullet$ & $\bullet$ & $\bullet$ & $\bullet$ & - & $\bullet$ & & $\bullet$ & & & & $\bullet$ & & \\
\hline Epidemiological surveys & & $\bullet$ & & & $\bullet$ & $\bullet$ & $\bullet$ & $\bullet$ & $\bullet$ & & $\bullet$ & & $\bullet$ & & & $\bullet$ & & $\bullet$ & & $\bullet$ \\
\hline $\begin{array}{l}\text { Occupational health } \\
\text { services management/ } \\
\text { policy development }\end{array}$ & & & & & & & & $\bullet$ & $\bullet$ & $\bullet$ & & & & & & & & & & \\
\hline $\begin{array}{l}\text { Employee occupational } \\
\text { health training }\end{array}$ & & & & & & & $\bullet$ & & & & $\bullet$ & & & & & & & & & \\
\hline Case management & & & & & & & & & $\bullet$ & & & & & & & & & & & \\
\hline $\begin{array}{l}\text { Psychosocial work } \\
\text { environment }\end{array}$ & & & & & $\bullet$ & & & & & & & & & & & & $\bullet$ & & & \\
\hline
\end{tabular}

Fuente: Staun J [17].

that specialists consider all aspects related to competences in the field of prevention to be more relevant. On the other hand, the highest degree of development is reached in the healthcare area $[13,14]$. The Federation of Occupational Health Nurses within the European Union describes the competences of the specialty in different countries (Table 1). Although the structure of the program differs depending on the country, the contents related to public and community and public health have a great weight in all cases. However, the professional federation itself points out two considerations: In six countries they have specific contents during the undergraduate period, and in twelve they have established specific specialization programs [15-17].

The demands of organizations and professional societies advocate the incorporation of indicators based on sensitive results, both in nursing practice and in clinical decision-making, highlighting the use of a specific nursing model focused on quantifying the contribution of managed care according to the previously defined objectives [18]. Without losing a more global perspective, there is a tendency to evaluate the nursing contribution in the comprehensive care process and not in isolation [19]. Therefore, delving into the definition of criteria that evaluate their profitability constitutes a priority criterion for analysis and research [20].
The universalization of worker protection against risks has allowed not only to take into account workplace accidents and occupational diseases, but also any damage to the health of the working population [21]. Hence, the Prevention Services Regulation [22] introduces the concept of work-related diseases, an aspect that opens up a broader line of research and analysis. Research proposals with a nursing perspective that allow us to delve into the influence of working conditions on the health status of the working population, contribute to increasing the heritage of the profession and increasing the quality of working life. Therefore, the responsibility and functions of this specialty should not be limited to health surveillance and provide emergency health care in the workplace, but should also extend its activity to circumstances that affect the health of workers [23-25] consistent with the definition of occupational health [26].

We must not overlook the fact that the occupational health nursing specialty is in a privileged position to identify the needs of organizations in the field of its competences. Considering the active role it plays in the work context, its contribution is evident to guarantee the well-being of the people who are the object of its care, the working population. And its future comes hand in hand with providing cost-efficient quality care [27]. 


\section{References}

1. González-Caballero J (2020) Training in occupational health nursing competencies: An ongoing review. Eur $\mathrm{J}$ Occ Health Nurs 1: 84-93.

2. González J (2020) Estudio sobre las competencias profesionales de enfermería del trabajo en España. Arch Prev Riesgos Labor 23: 34-51.

3. http://www.boe.es/boe/dias/2009/05/28/pdfs/ BOE-A-2009-8880.pdf

4. https://www.boe.es/doue/2013/354/L00132-00170.pdf

5. h t t ps://ww w . boe.es/buscar/pdf/2017/ BOE-A-2017-6586-consolidado.pdf

6. WHO (2001) The role of the occupational health nurses in workplace health management. World Health Organization Regional Office for Europe, Copenhagen.

7. American Association of Occupational Health Nurses (2020) Health promotion and productivity in the workplace: The occupational and environmental health nurse role in supporting the workforce using NIOSH's Total Worker Health ${ }^{\circledR}$ approach. Workplace Health Saf 11.

8. Vega Ruiz ML (2020) Is work healthy? Arch Prev Riesgos Labor 23: 410-414.

9. Campbell J, Koca F (2021) Financing and protection for the health and care workforce. Bull World Health Organ 99: 2.

10. Maqueda J (2016) Formación en medicina del trabajo: Competencia y sostenibilidad. Med Segur Trab 62: 126134.

11. Arranz S, Carcedo S (2010) Metodología enfermera: Una necesidad en salud laboral. Tesela 7.

12. Carrión A, Núñez C (2011) Presencia enfermera en la comunidad virtual sanitaria. Metas de Enferm 14: 3.

13. Rogers B, Kono K, Palucci MH, Peurala M, Radford J, et al. (2014) International survey of occupational health nurses' roles in multidisciplinary teamwork in occupational health services. Workplace Health Saf 62: 274-281.

14. González J (2017) Evolución y desarrollo de las competencias profesionales de enfermería del trabajo. Universidad del País Vasco/Euskal Herriko Universitatea, Bizkaia.
15. Education Group, FOHNEU (2012) Occupational health nursing education, practice and profile in the EU countries. Final Report.

16. Education Group, FOHNEU (2004) Occupational health nursing education and practice in the EU countries. Final Report.

17. Staun J (2014) OHN status in EU member states 20052012 final results. The Federation of Occupational Health Nurses within the European Union (FOHNEU).

18. Occupational Health Nursing Working Group (2016) Educating occupational health nurses. An approach to align education with a service vision for occupational health nurses. Royal College of Nursing, London.

19. Moorhead S, Johnson M, Maas ML, Swanson E (2009) Clasificación de Resultados de Enfermería (NOC). Elsevier, Barcelona.

20. Sirgo PG (2016) Nuevas perspectivas para la salud laboral en un marco público y privado. Med Segur Trab 62: 178187.

21. http://www.boe.es/boe/dias/1995/11/10/pdfs/A3259032611.pdf

22. http://www.boe.es/boe/dias/1997/01/31/pdfs/A0303103045.pdf

23. https://www.mscbs.gob.es/ciudadanos/saludAmbLaboral/ docs/portadaLibroBlanco.pdf

24. https://www.mscbs.gob.es/ciudadanos/saludAmbLaboral/ docs/guiavigisalud.pdf

25. https://www.osalan.euskadi.eus/libro/vigilancia-epidemiologica-en-el-trabajo-guia-para-la-implantacion-de-la-vigilancia-colectiva-por-parte-de-los-servicios-de-prevencion/ s94-osa9996/es/adjuntos/guia_vigilancia_epidemiologica_2015.pdf

26.https://www.boe.es/boe/dias/2011/10/05/pdfs/ BOE-A-2011-15623.pdf

27. Martínez C, Monforte-Royo C (2012) Research beyond clinical nursing. Enferm Clin 22: 63-64. 